\title{
"Distinguished" women entrepreneurs in the digital economy and the multitasking whirlpool
}

Irene Kamberidou(D)

\author{
Correspondence: ikamper@phed. \\ uoa.gr \\ National and Kapodistrian University \\ of Athens, Athens, Greece
}

\begin{abstract}
How are women entrepreneurs transforming and challenging traditional understandings of professional success in the 21st century, despite the multitasking whirlpool? What type of knowledge and skills are required in today's digital world to develop professionally and succeed as an entrepreneur? What are the major barriers to successful entrepreneurship preventing women from realizing their full potential or stopping them from even beginning an entrepreneurial career? A current literature review (2011-2019) on women's entrepreneurial initiatives, skills, characteristics, attributes, motives and leadership styles, documenting strategies for success and barriers confronted, indicates that not much has changed. Women entrepreneurs continue to face the multitasking whirlpool, along with the lack of financial resources, marketing skills and support services, including poor access to business networks, technology and digital markets. Despite the mass entry of women in exclusively male domains, glass ceilings have not been shattered. Then again, developed and developing nations have come to understand that women's entrepreneurial activities contribute to socioeconomic growth and utilizing the full potential of all human resources is essential for sustainable development. Studies of the 21st century - as those of the late 20th century - continue to spotlight gender gaps in entrepreneurship as well as the sovalued career-family balance, while still arguing that further research is needed. They also agree that successful entrepreneurship requires digital skills along with the drive for innovation. The successful entrepreneur, or to use a term and concept coined by Elias $G$. Carayannis and McDonald R. Stewart (2013), the "distinguished entrepreneur" regardless of gender, is an innovator; a visionary; a person who predicts and shapes the future; takes initiatives; accepts change, risk and failure; learns from it; and sees what others do not see, among other things. Accordingly, this study presents snapshots of lives changed and empowered. It includes the work and narratives of "distinguished" (Carayannis \& Stewart 2013) women entrepreneurs who have made a difference. Is it not time to shed some light on inspirational role models, especially those who are excelling in the startup world, the Blue Economy and the Silver Economy?
\end{abstract}

Keywords: Women, Entrepreneurship, Multitasking whirlpool, Gender participation gap, Gender pay gap, Gender leadership gap, Work-life balance, Digital skills, Degendering

\section{Introduction and Background}

\section{Have we moved forward?}

The numerous and diverse benefits of female entrepreneurship have been researched in great detail since the mid 1980s and repeatedly associated with concepts of

(c) The Author(s). 2020 Open Access This article is distributed under the terms of the Creative Commons Attribution 4.0 International License (http://creativecommons.org/licenses/by/4.0/), which permits unrestricted use, distribution, and reproduction in any medium, provided you give appropriate credit to the original author(s) and the source, provide a link to the Creative Commons license, and indicate if changes were made. 
empowerment, leadership, independence, personal growth and professional development, increasing women's quality of life and contributing to the economy. Older studies focusing primarily on Western societies, provided critical overviews on women's entrepreneurial activities and small business ownership, while discussing (1) motives for starting or leading a business; (2) female leadership styles, management skills and strategies; (3) social expectations or gender barriers, including the work-family conflict; (4) satisfying personal-individual needs while running a business; (5) women's choices resulting from changing sociocultural dynamics; and (6) the characteristics of the successful female and male entrepreneur or business-owner. With regard to the latter, researchers tended to compare women to men, frequently concluding that women are more similar to men than they are different, in terms of both demographic and psychological characteristics, and that successful women entrepreneurs are similar to men in terms of innovation, vision, risk-taking, competitive skills, persistence, goal setting and leadership (Carlsrud \& Olm, 1986; Chaganti, 1986; Neider, 1987; Hisrich \& Brush, 1987; Phizacklea, 1988; Smeltzer \& Fann, 1989; Fagenson \& Marcus, 1991; Buttner, 1993; Ferguson \& Durup, 1997).

A growing body of research (2011-2019) continues to discuss the behavioral characteristics, attributes, motives, skills and leadership styles of the female entrepreneur, along with the obstacles confronted, documenting case studies and strategies for success. Certainly, the drive for innovation is the first criteria for successful entrepreneurship, or to use a term coined by Elias G. Carayannis and McDonald R. Stewart (2013), the "distinguished entrepreneur", regardless of gender, is an innovator; a person with a vision; an individual who takes initiatives; accepts change, risk and failure; and organizes and re-organizes social and economic mechanisms, among other things.

So, have we moved forward? It seems the same questions are being investigated in the 21st century, as most of the anachronistic gender barriers and social expectations are still out there, in addition to the digital skills gap. Current studies continue to emphasize the social and economic benefits of female entrepreneurship and leadership (Scuotto et al., 2019; Etim \& Iwu, 2019; Khan \& Rowlands, 2018; Singh 2017, Chengadu \& Scheepers, 2017, Cesaroni et al., 2017; Rajani \& Panicker, 2017; Alsos, Hytti, \& Ljunggren, 2016; Ohr, 2016; Nair, 2015; Harrison, 2015; Agarwal \& Lenka, 2015; Kamberidou, 2013; Salamouris, 2013).

Developing economies are also recognizing and focusing on the socioeconomic benefits of women's entrepreneurship as a means of escaping poverty and contributing to economic growth while challenging the gender order. Research shows that women's entrepreneurship in the so-called "emerging countries" Cesaroni et al., 2017), although appreciated in alleviating poverty, is being disputed or restrained since it challenges traditional understandings of gender. Clearly, women entrepreneurs confront greater sociocultural barriers than their western counterparts in the emerging markets of Africa, the Middle East and the Far East (Etim \& Iwu, 2019; Nsengimana et al., 2018; Chengadu \& Scheepers, 2017; Mazonde, 2016; Manimekalai, 2016; Zahro, 2016; Mutalib et al., 2015; Liliani and Urbanus, 2014; Abdul \& Hashmi, 2014).

Studies continue to argue that a key prerequisite for entrepreneurial success is lightening women's domestic workload and especially in the patriarchal societies of developing economies where the sandwich generation prevails, namely societies in which women are the primary homemakers and caregivers, regarding responsibility for 
housework, children and older dependent family members. For example, in the patriarchal societies of Rwanda, India, Pakistan and South Africa, empirical evidence confirms that women's entrepreneurial endeavors are usually discouraged or constrained (Nsengimana, Chux \& Robertson 2018; Singh 2017; Rastogi 2015; Abdul \& Hashmi 2014; Anwar \& Rashid 2012; Ndovela 2016; Nambiar 2016, Fatoki 2016).

\section{Gender neutral attitudes and "efficient innovative entrepreneurs"}

Misinterpretations and misconceptions regarding women's entrepreneurial role continue as well, indicating that we still have a long way to go. To illustrate, in her study, Nasim Tavakol (2017) misapprehends Kamberidou's (2013) article in Springer, "Women entrepreneurs: we cannot have change unless we have men in the room", which supports or calls for gender-neutral or gender-inclusive perspectives, that is to say collaborations and teamwork between men and women; both genders working together to achieve economic growth and sustainable development. Instead, Tavakol (2017) argues that women are unable to move forward unless they have "a man at home." Accordingly, could she have argued that men are unable to move forward unless they have a woman at home?

Additionally, if we incorporate the digital skills gap into the discussion then the picture is even gloomier, and especially in the developing world (Fatoki, 2016; Tran, 2014). The exclusion of a sizeable part of the workforce from the digital economy-and women in particular-indicates that we have not come a long way in rethinking the digital divide. Competing successfully in today's global economy requires innovation in addition to enabling technological development within industries, organizations and companies (Carayannis \& Campbell, 2018; Carayannis \& Meissner, 2017).

Despite the progress made in recognizing and applauding women's entrepreneurial innovations, initiatives, contributions and development (Scuotto et al., 2019, et al.), women entrepreneurs are underrepresented in Europe. They make up only $29 \%$ of entrepreneurs (11.6 million), a meagre 3\% increase since 2008. Women also represent the majority of one-person enterprises in Europe (78\%) and continue to establish businesses in fields like social services, social work, health care and education ${ }^{1}$. Women are the largest untapped entrepreneurial and leadership potential in Europe, and particularly in the tech. sector, although digital tools are giving them the chance to build a business from home and create unique work schedules. More and more people today are using technology to work independently, market their brands or ideas, monitor results and manage their work-life balance (Kamberidou \& Labovas, 2012; Scuotto et al., 2019). Digital mobile lifestyles and virtual workplaces refer to new models of work with flexi-schedules, usually perceived as a benefit for women with children and associated with low commitment. This is untrue! Technology as an enabler means flexible working conditions for both women and men. The demand for greater flexibility is not only about motherhood. Parenthood-in Western societies in particular-is a role that men are increasingly sharing.

\footnotetext{
${ }^{1}$ This report presents the key findings of an analysis of available data on women entrepreneurs in Europe-37 (specifically, 37 countries, including the 28 EU Member States). It includes data on women and men entrepreneurs active in Europe-37 and the percentages of entrepreneurs in the active labor force, to wit entrepreneurship rate: data provided on solo entrepreneurs and entrepreneurs who are employers (European Commission 2014: 7).
} 
Men are also seeking the precious work-life balance, although it is still predominantly women who confront the multitasking whirlpool ${ }^{2}$, a term I use to best describe women's-repeatedly documented-experience of being pulled in all directions: juggling professional, social, family and domestic obligations while pursuing individual or creative goals and needs. The multitasking whirlpool is a result of sociocultural expectations related to gender role ideologies that have led to the pattern of having to do it all, specifically the superwoman-superhuman identity. Women are experiencing multiple levels of tension and contradictory feelings due to this conflicting social roles or the superwoman identity, along with "gender fatigue", the latter a term and concept coined by Elisabeth K. Kelan (2009).

Sucheta Agarwal and Usha Lenka (2015: 356) describe this tension as "role conflict", arguing it is detrimental to women's physical and mental health and causes behavioral changes. However, they do not explain what they mean by behavioral changes. In their literature review using secondary data, selected papers from 1988-2014, they point out that in order for women to overcome this role conflict "they need to balance between work and personal lifestyle", adding that in order to accomplish this and gain more flexibility, they choose to start their own business or embark on an entrepreneurial career. Moreover, they propose that women entrepreneurs "should encourage the involvement of family members in their entrepreneurial ventures so that they get enough time to spend with their family," adding that they should not "bring back office work to home or vice versa," and should follow a schedule, avoid procrastination and spend their vacation time with family members.

It seems we still have a long way to go in acknowledging the necessity to eliminate gender stereotypes, but lightening women's domestic load is only part of the solution. It is also vital to eliminate discrete forms of gender discrimination (the invisible barriers to engagement/employment and advancement), such as the glass ceiling, the glass escalator, the sticky floor and the leaky pipeline. In other words, the gender leadership gap, pay gap and participation gap, which indicate that integrating the gender dimension into social structures, policies, institutions and research is vital. Integrating the gender dimension means eliminating gender devaluation, viz. the subtle processes by which women's contributions are minimized, undervalued, or devalued (Fig. 1).

Scholars and researchers of the 21st century-regarding the significance of women's entrepreneurial activities-have been providing sophisticated and thoughtful insights, some overemphasizing the role played by women entrepreneurs and others downplaying it. Certain researchers homogenize women, reducing them into typical social models, arguing that a high proportion of women have a fear of failure while others assert that women entrepreneurs are highly ambitious, open to challenges, love to take risks and pursue their goals dynamically. When examining innovation, managerial approaches or leadership styles, researchers describe female entrepreneurs as more democratic, interactive and transformational, arguing that women are better listeners than men and have a greater tendency to collaborate and share information and knowledge. They also observe that women enjoy a slight edge over their male counterparts when it comes to group communication skills while pointing out that the collective intelligence

${ }^{2}$ Multitasking Whirlpool: Term coined by Dr. Irene Kamberidou. Copyright May 14, 2018@ https:// www.nlg.gr/ Additionally, term-concept registered to Notary Public and IPR date available from Hellenic/National Postal Service (ELTA) June 2018. 


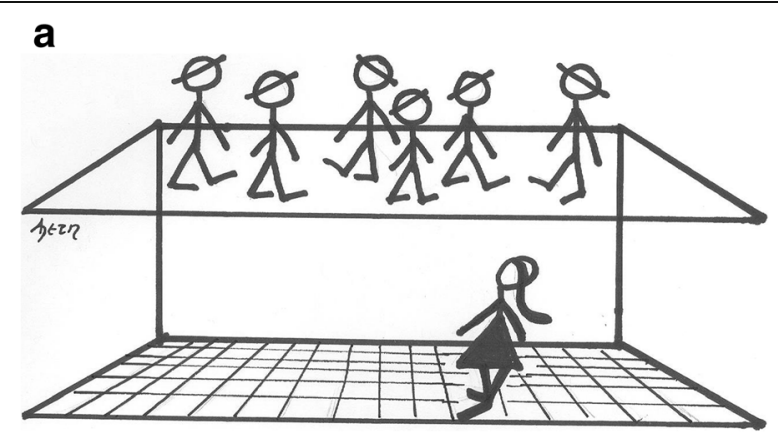

b

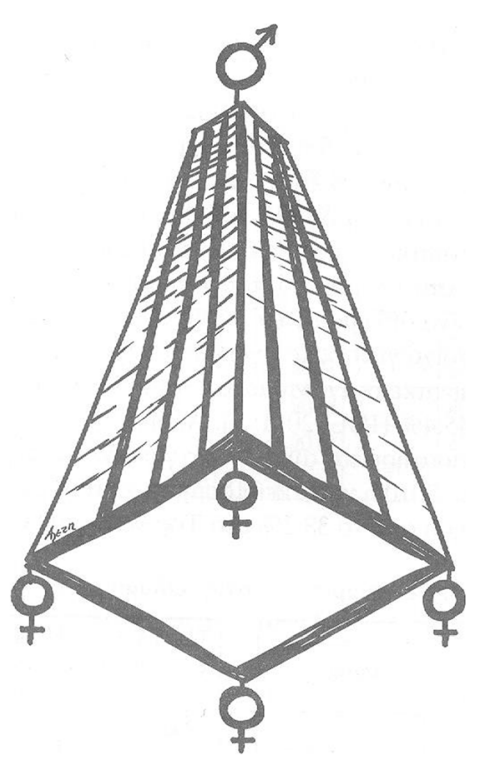

Fig. 1 a Glass ceiling, b leadership gap

of a group rises when the group includes more women (Kamberidou 2013, Kamberidou \& Fabry, 2012), which indicates that diversity and integrating the gender dimension is essential.

A great number of studies, especially in the last two decades, have been recommending the implementation of legislation, policies and practices that encourage long-term female entrepreneurial involvement and foster socioeconomic development. For example, Rupali Jitendra Khaire (2011: 36) calls for the implementation of statutory policies to promote women's empowerment as "efficient innovative entrepreneurs". To motivate women entrepreneurs, she proposes providing training opportunities exclusively for women along with financial assistance and establishing policies, practices and arrangements that would "lighten women's domestic workload".

Ayesha Kalim (2012) also follows this line of thought, adding that equal opportunity policies need to be framed for women entrepreneurs, including well-defined property rights, transparency and the rule of law. Legal scholar Emile Loza (2011) recommends focusing on innovation-driven female entrepreneurship. She argues that the legal academy has done nothing on female entrepreneurship, although women are critical contributors of economic growth and "an economic and development engine" (Loza 2011: 44). In her study on the development of women's entrepreneurship from a range of 
other academic disciplines, she argues that further research is needed on innovationdriven female entrepreneurship. She recommends the legal academy enter the field of entrepreneurship study with a unified definitional taxonomy, while advising entrepreneurship scholars to approach their work with interdisciplinarity.

Nancy Pascall, DG CONNECT, Principal Administrator-Policy Coordinator, European Commission Brussels, has been contributing significantly to discussions on integrating a gender perspective into policy-making at European, international and national levels. She provides original and exclusive information into initiatives that could increase the number of women in the cybercommunity. For example, in her study titled Engendering technology, Empowering Women, Pascall (2012) shows how ICTs can become a means or an effective tool for social equity. She discusses policies and programs, such as the "Small Business Act", which promote women entrepreneurs, including measures to promote entrepreneurship among women graduates. She also discusses practices and legislation under the mandate of DG EMPL, supported in the context of the business-led European Alliance for corporate social responsibility (CSR) with laboratories on "mainstreaming diversity in the company" and "equality between women and men". Her research on women innovators and entrepreneurship highlights how to make better use of women's potential and contribution to Europe's competitiveness. She argues for the active participation of women in the invention and development of technology, and specifically in decisive roles in design, production and entrepreneurship. Her focus is on new participative competencies and how to link and support entrepreneurs in businesses related to science, engineering, technology and information technology. With respect to businesses related to the STEM sector, she discusses how to promote entrepreneurship in the field of engineering for both women and men.

An excellent example of such an engineer-entrepreneur is Solomon Mensah from Ghana, who was raised in the slums of Takoradi. Driven by personal motivation, to help children born in the developing world, Mensah, an engineering doctoral student at Northeastern University, co-founded a startup Therapeutic Innovations which is focused on creating lessexpensive versions of Western medical equipment for use in developing countries. The first product was a device to help newborn babies breathe-respiratory problems being a common cause of death for newborns in the developing world (Coppola, 2018).

Siti Zahro (2016) proposes applying entrepreneurship in engineering education as a means of eliminating the unemployment of the engineering graduates at the National Yunlin University of Science and Technology in Taiwan. Zahro (2016) calls for the development of strategies to encourage entrepreneurship-focusing on learning design for engineering education in combination with practical experience in entrepreneurship-with teachers serving as facilitators in motivating students along with the support of community leaders, faculty members and stakeholders. She adds that it is necessary to build financial support for the production processes, encourage reflection, impose quality control, stimulate the selling procedure and carry out evaluations for every process to improve the quality of the products.

As regards the digital entrepreneur, Parul Malik (2017) argues that women's entrepreneurial journey is difficult, even in the emerging digital landscape. She discusses the need to develop policies that support practices that enable women to pursue careers as digital entrepreneurs. The importance of studying policies and ensuring their implementation 
through agencies is also emphasized in Khaire's (2011) critical analysis of statutory policies for women's empowerment and entrepreneurial impact. In examining theoretical and methodological contributions to women's entrepreneurship, she argues that the major player in entrepreneurship development is the state. She describes policies as dynamic blueprints, basic principles and declared objectives that have to be implemented. She argues that social policies are what happens "on the ground" when they are implemented, adding that it is the government's responsibility to achieve and preserve them in the interest of national communities. With regard to the new generation, Khaire (2011) argues that entrepreneurship development is perceived as a way to promote selfemployment, especially among educated youth, as well as a means to sustain economic development and increase competitiveness. The industrial and agricultural sectors, she adds, offer a threshold for the new generation of entrepreneurs to carry out radical changes, especially in production and distribution.

In her analysis on the attributes of a successful entrepreneur, Khaire (2011) points out that the first criteria is innovation, as observed in developed countries such as the USA, the UK and Canada, adding that "efficient innovative entrepreneurs", through their ideas and far sightedness, are the ones who have contributed to creating strong economies for industrially and economically developed nations.

\section{Characteristics of the successful entrepreneur: obsessed maniacs and clairvoyant oracles}

The critical attributes, competency and behavioral characteristics of the successful entrepreneur are brought to light in an empirically validated study of entrepreneurial behavior by Carayannis and Stewart (2013): "The distinguished entrepreneur", they argue, predicts events and conditions accurately and in advance for superior strategic positioning, adding "We find that two terse descriptors-obsessed maniacs and clairvoyant oracles-encapsulate critical attributes conducive to superlative entrepreneurial posture, propensity and performance to anticipate and recognize challenges and convert them into opportunities" (Fig. 2).

To investigate this premise and develop personal profiles of the vital attributes and behavioral characteristics of the distinguished entrepreneur, Carayannis and Stewart (2013) conduct comprehensive surveys and interviews with 33 founding entrepreneurs, analyzing their experiences against complementary data sources. Using qualitative analytic techniques, they found the data rich in empirical evidence to support a perspective of entrepreneur as an "obsessed maniac and clairvoyant oracle", including many other intrinsic characteristics of personality, intention, motivation and action that make up the entrepreneurial actor.

In pursuing a vision, the successful entrepreneur leverages strategic knowledge, serendipity factors, technology foresight, unrelenting persistence and practice and strategic knowledge arbitrage competences. In other words, the distinguished entrepreneur, according to Carayannis and Stewart (2013), is not only able to predict the future, but also anticipate and shape it. He or she will accurately predict events and conditions before they occur, which permits strategic positioning of the venture for optimal advantage. The successful entrepreneur, they argue, is focused yet flexible, demonstrates relentless intensity of purpose while adapting that purpose under changing conditions. 


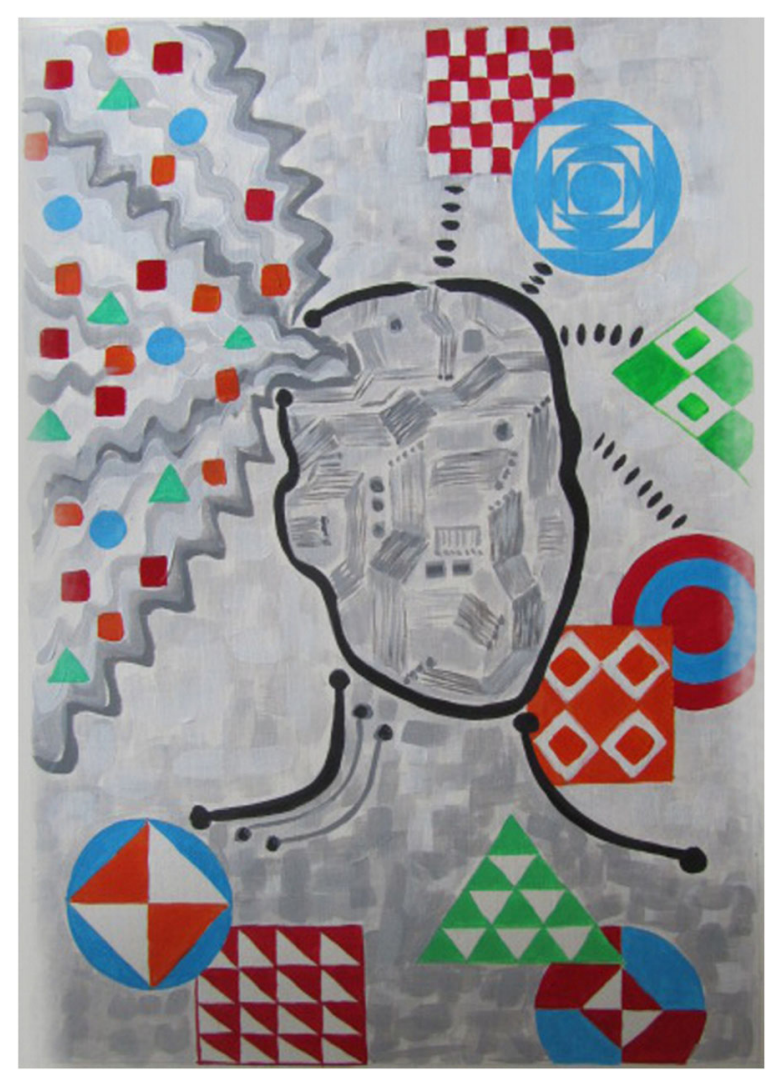

Fig. 2 Creativity and entrepreneurship. By the artist Areti Kamperidis, first published in Journal of Innovation and Entrepreneurship, A SpringerOpen

Journal: https://innovation-entrepreneurship.springeropen.com/track/pdf/10.1186/2192-5372-2-6

In technology markets, Carayannis and Stewart (2013) assert, starting a new business venture is particularly tenuous due to the competitive and strikingly turbulent and stochastic environmental forces that require the relentless pursuit of a self-assured vision, and more specifically "learning-to-learn and learning-to-learn-how-to-learn". The successful entrepreneur begins with a vision, an idea, an initiative, or the urge to proceed. Successive and evolutionary execution of entrepreneurial ambition not only createsfirms and organizations that generate industries which in turn create institutions-but also revises, destroys and replaces complex economic systems and businesses that can sustainably perform and thrive, even in the later absence of the founding entrepreneur, in other words after he/she has moved on.

Drive, perseverance, personal ambition and a degree of mania are among the characteristics cited for the distinguished entrepreneur. As an example, Carayannis and Stewart (2013) refer to an old case study, that of Madame Walker, whose ambition was so great, even though her revenues reached only 10 dollars a week and her husband tried to persuade her to slow down. Walker set up an office in Pittsburgh, a factory in Indianapolis and a salon in New York City. She built a sales force of 2000 mainly black women who were trained in hairdressing and in sales techniques at company-run schools.

Additionally, Carayannis and Stewart (2013) use the following terms and phrases to describe the characteristics and attributes of the distinguished entrepreneur: knowledge of what he or she does not know, knowledge of what is outside a personal span of 
control, intelligence, analytical abilities, learning to be an entrepreneur, experience, adaptability, intuition, creativity, innovativeness, integrity, vision, living in the present but dreaming of the future, seeing what others do not see, natural salesmanship, persuasiveness, exceptional credibility, reputability, experiencing good fortune or happy accidents, actively positioning oneself for opportunity, forming strategic networks and alliances, investing in strategic plans, targeting, goal setting, investing personal resources in a business idea and accepting change. Undeniably, all these characteristics are a guarantee to success in any discipline or profession.

In their in-depth analysis of the technology entrepreneur, they describe innovation as the market actualization of better ideas, the cultivation of knowledge, the transformation of an invention into a socially usable product. The drive for innovation, they argue, is a dynamic process and the first criteria for successful entrepreneurship, as are digital skills in technology-driven environments. In their discussion on invention, they argue that invention is a singular event born of science, research, discovery, creativity and serendipity which does not always impact or influence technology. Whereas innovation is not just invention, but an interactive process. Innovation-often associated to the creation of a sustainable market around the introduction of new and superior products or processes-is not just invention but an economically viable adaptation, improvement, or application of a technology via exploration and exploitation (Carayannis \& Stewart, 2013).

Stella Bezergianni (2013) also argues that the basis for technological creativity and innovation is conceiving and exploiting new ideas, adding that the most important step is the conception of a new idea having the potential to be transformed to a successful business solution. In her study on the exploitation of waste cooking oil-which is abundant in Greece and other Mediterranean countries-she presents an innovative idea. Specifically, a new green technology for producing diesel from residual feedstocks, an idea conceived and developed in Greece, at the Centre for Research and Technology Hellas.

In Italy, Scuotto et al. (2019) discuss the shift towards a digital business model for the female and male entrepreneur. Using a ground test theory, they analyze two case studies, categorized as small to medium enterprises-operating in the creative industry in the city of Turin, Italyagainst six dimensions of the business model framework: value proposition, target market, value chain, value network, revenue mechanism and competitive strategy. This is used as a basis to compare a female and a male digital entrepreneur. According to their findings, both male and female entrepreneurs emphasize the relevance of the digital approach in the abovementioned six dimensions of the digital business model, highlighting the importance of the "value network" to improve the working experience of the employees and that of the customers. Citing the 2016 Global Entrepreneurship Monitor estimate that there are around 163 million women entrepreneurs, the authors point out that "despite this, woman entrepreneurs are still treated differently to their male counterparts and as the online space is integrated with offline space and so the gender inequality persists" (Scuotto, et al. 2019:121).

\section{Results and discussion}

\section{Digital entrepreneurs and the multitasking whirlpool}

Women's entrepreneurial journey is difficult, even in the emerging digital landscape. Studies on women entrepreneurs of the 21st century-as those of the late 20th- 
indicate that women are continuing their quest for a work-life balance, personal fulfillment and meaning through entrepreneurship rather than profit first, consequently choosing to become micro-entrepreneurs or home-based entrepreneurs.

In their pursuit for flexibility and balance, they experience multiple levels of tension and stress, a result of the multitasking whirlpool, as previously cited, a term and concept I use to describe the results and consequences of social expectations and gender role ideologies that have led to the women-doing-it-all pattern (or being pulled in every direction): managing professional, social and family responsibilities/obligations, namely gendered expectations, duties and individual needs, and as a result, experiencing confusing-contradictory-conflicting feelings and emotions.

On the other hand, studies also confirm the effectiveness of ICTs in providing flexihours and helping women start, grow and sustain a business: lower costs, networking and work-life flexibility. Undeniably, technological advances are enabling women to engage in digital entrepreneurship; however, entrepreneurship remains a gendered activity and women are still being drawn into the confusing and tumultuous multitasking whirlpool.

This is clearly demonstrated in Parul Malik's (2017) dissertation on women digital entrepreneurs. Malik (2017) analyzes data from 30 in-depth interviews with US-based women digital entrepreneurs, using a "tension-centered approach". Her findings show that women experience multiple levels of tension in their creative pursuits along with social pressures to find a real job, in the real world as opposed to the virtual environment or working online from home while managing social and family obligations. They experience multiple tension levels when they (a) negotiate and embody dominant social discourses on entrepreneurship, (b) set up their careers and (c) perceive opportunities and challenges in the emerging virtual landscapes.

Malik (2017) also argues that women digital entrepreneurs experience "contradictory pulls" due to societal messages or social expectations concerning multiple roles across public and private spaces. Her study shows how gendered processes are constantly shaping digital entrepreneurship outcomes. It adds to the research on the difficulties women confront in their entrepreneurial journey and highlights the need to develop policies that support practices that will enable and support women digital entrepreneurs in their work.

The evolving digital landscape is examined in another study which focuses on the reasons women decide to become digital entrepreneurs. The findings show that a primary motivation is gaining independence from the patriarchal, hierarchal and malecentric structures of the corporate workplace, and not only. Passion, love, freedom, flexibility and becoming members of the female entrepreneurship community were the terms and concepts used by the 55 female participants who took part in the study. In her dissertation at Trinity Washington University, using both qualitative and quantitative methods, and 55 participants, Kim Tran (2014) analyzes the impact of digital media on the process of female entrepreneurship and why women decided to become entrepreneurs. The Social Identity Theory, the Uses and Gratification Theory and the Gender Communication Theory were applied to identify correlations between new digital media tools, social platforms and communication traits on how women start and operate their businesses in the digital landscape.

The primary motivations of the 55 participants were more abstract or emotionally oriented and rarely financial-based. The findings confirm that women pursue personal 
fulfillment and meaning through entrepreneurship rather than profit first and foremost. Moreover, the significant impact of digital media on helping women start and sustain a business is also confirmed in the study. Tran's (2014) findings indicate that half of the female entrepreneurs that participated in the study conduct their businesses online over $75 \%$ of the time; the majority listed Facebook and Twitter as the primary digital media tools employed in operating their businesses. The findings also show that building rapport is now a contextual necessity on digital and social platforms, such as creating a loyal Facebook and Twitter following by strengthening and nurturing customer relationships on a long-term basis, which she argues has no bearing on communication patterns being either "masculine" or "feminine". Participants also reported "writing" and "listening" as their primary communication skills, essential in the formation and maintenance of social relationships in online-based environments. She concludes that a strong, positive correlation between digital media and female entrepreneurship does exist for the majority of the participants. It relieves women of many financial burdens when starting a business, the majority stating that it would have been very expensive to establish and grow their businesses without digital media tools and platforms.

With respect to businesses related to the STEM and ICT sectors, Pascall (2012) examines new participative competences and networks and how to link and support entrepreneurial activities. She argues that engendering ICTs entails the presence of women as part of the dynamic communities shaped by the rapid development of technology, since the new world is characterised by the formation of these communities which lead to an ever-increasing demand of ICT services. A concept effectively supported in her dissertation is that ICT is an agent of change, a major driver of innovation and economic and social modernization-critical to the future of Europe and economic sustainability. As previously cited, Pascall (2012) provides original and exclusive information into initiatives-European, international and national-aiming to increase the number of women in the cybercommunity. Her last chapter presents concrete proposals for policies and decision-makers, i.e. female-friendly design and production that would lead to an increase in participation, more women as end-users and as ICT and technology professionals. Seven years later, in another study, she examines today's digital skills crisis focusing on the factors that contribute to digital exclusion, in addition to the digital skills that are becoming increasingly essential for entrepreneurial activity, employment and employability, getting access to a range of services, products, and so forth (Kamberidou \& Pascall, 2020).

Building upon the latest research, Kamberidou and Pascall (2020) address the gender imbalance in ICT and related sectors in the 21st century. Focusing on the digital skills gaps associated with the exclusion of a sizeable part of the workforce from the digital market economy, and women in particular, they argue that the gender imbalance in ICT and related sectors persists today. Additionally, they point out that engendering ICTs and STEM entails women's engagement, not only as entrepreneurs, but as technology professionals, specialists, leaders, policy makers, producers and researchers. They conclude that women are still underrepresented and digitally excluded, and efforts to attract, recruit and retain girls and women in ICT and STEM seem to be failing, reinforcing the three gender gaps (participation gap, pay gap and leadership gap), a result of the deep-rooted gender order which is clearly reflected in the latest Global Gender Gap Report and Index. Moreover, they emphasize that exclusion from the digital market is augmented and reinforced when the gender dimension is combined to other exclusionary factors such as disability, age, race and socioeconomic background. 
Kamberidou and Pascall (2020) argue that engendering ICT and STEM education, and raising the profile of female role models, mentors and leaders is essential to inspire more girls and women into technology and reproduce participation. Accordingly, following a series of semi-structured interviews, their paper includes recommendations from three successful role models, mentors and leaders in ICT, STEM and Information Society, specifically social entrepreneurs who have made a difference. The three role models-Elizabeth Pollitzer (UK), Rosalie Zobel (USA, UK) and Olga Stavropoulou (Greece)-propose engendering technology and STEM education to increase the female talent pool, that is to say, integrating the gender dimension. To illustrate, "Digital skills today are as vital as electricity so go and get them! Rethink how ICTs are presented to girls and women. Compelling evidence shows that women are more sensitive to context so we need to develop the cyber-physical and offer a richer content [...] We need to create female-friendly designs and production to increase women's engagement and participation, and improve female representation in STEM," argues the Director of Portia Ltd., Elizabeth Pollitzer, who also founded the Gender Summit (https://gender-summit.com/) which she organizes annually.

The Gender Summit is a platform where scientists, policymakers, gender scholars and stakeholders in science systems work together to achieve gender equality in research, innovation and STEM. The Gender Summit started in Europe in 2011, influencing how gender is addressed in Horizon 2020, the biggest EU Research and Innovation program ever with nearly $€ 80$ billion of funding available over 7 years (2014 to 2020). These summits have brought together over 5000 participants from science scholarship, STEM and industries from Europe, North America, Latin America, Africa and Asia-Pacific (Kamberidou \& Pascall, 2020).

"Cultivate your leadership skills, and learn how to manage people. At some point, if your career progresses well, you will be a manager. You will not be able to do everything yourself, so learn to delegate. [...] Decide what you want to do and then do it! Don't get side-lined in other jobs!" advises Rosalie Zobel, former Director in DG INFSO (Information Society) Directorate C: Components and Systems-and former Chair of the High Level Group of the European Centre for Women in Technology (ECWT). Rosalie Zobel contributed to encouraging hundreds of girls and women in ICT by working on policy to include women in the sector. She also fostered many concrete actions such as the setting up of the ECWT, which was a DG INFSO C's director's team concept that materialized thanks to her support.

"Via grassroots communities use soft skills [...] we look into transforming a digital mind-set based on soft skills empowerment platforms that minimize digital fear and resistance through actual data, daily practices and hands on experience, rather than beliefs that hold women back from digital evolution and inclusion," argues social entrepreneur Olga Stavropoulou, who is President of Militos Emerging Technologies \& Services, the Coordinator of the Hellenic Unit of the European Network of Mentors for Women Entrepreneurs (Business Mentors), and the Lead Coordinator of the 'Mellon W'network that up-skills unemployed women through the Mellon Skills Accelerator of Knowl Social Enterprise (Kamberidou \& Pascall, 2020).

Going beyond Western contexts, research confirms that entrepreneurs in developing economies face many more obstacles than their western counterparts, and when you incorporate the gender dimension into the equation, the obstacles are even greater. The main barriers that worry potential female entrepreneurs in the developing world 
are social stigma, gender inequalities, inability to maintain a work-life balance; lack of information, available opportunities, resources, support and finance; fear of risk; inability to make proper assessments; and the digital divide, digital exclusion or lack of basic digital skills.

Understanding how it feels to be a woman entrepreneur in a patriarchal society: women entrepreneurs in the developing world

"Female entrepreneurship is in itself a different phenomenon as compared to male entrepreneurship, requiring a separate model to explain it...There is a dire need to give a voice to these faceless and voiceless females who play a bigyet in general unseen-role towards making a household financially stable." (Anwar \& Rashid, 2012) Fig. 3.

Customs, beliefs, culture and religion amplify and reinforce gender inequalities and gender gaps, and not only regarding entrepreneurial activities. In patriarchal societies of the developing world women confront greater sociocultural barriers than the multitasking whirlpool (Fig. 4). Family or the immediate social environment plays a major role in constraining any type of public activity, consequently discouraging female entrepreneurship and leadership. Females are generally perceived as being submissive and subservient to the male gender, a social reality which is "more prevalent in Islamic contexts, which are characterized by conservative and patriarchal societies" (Mehtap et al., 2016).

Social expectations related to women's identity and primary roles-family-related responsibilities and domestic duties-intensify obstacles to self-employment. Women are responsible for all household work, which is much heavier in rural areas with large family units-the extended family as opposed to the nuclear-increasing barriers to selfemployment. This constraint applies to single women as well, since parents are concerned about a daughter's reputation and honor, especially regarding future marriage prospects. If a single woman is perceived as independent, dynamic, self-sufficient or domineering, in a society that values the submissive nature as a woman's greatest asset (a female's shyness and meekness), she is socially stigmatized and unable to find a husband (Okeke-Uzodike, Okeke-Uzodike et al., 2018, Chengadu \& Scheepers 2017, Rajani \& Panicker 2017, Mazonde 2016, Anwar \& Rashid 2012).

Focusing on understanding how it feels to be a woman entrepreneur in a patriarchal society, Nsengimana et al. (2018) assert that religion, culture and customs strengthen gender gaps. Their study on patriarchal perceptions that discourage women from embarking on entrepreneurial careers involves 398 women entrepreneurs in Kigali Rwanda. The main research question being: "How does being a woman affect the running of your business?" The 398 women entrepreneurs - the majority in business from 2 to 10 years, $64.6 \%$ in retail and $33.7 \%$ in services-were asked to complete a survey questionnaire. The data were analyzed using the Statistical Package for the Social Sciences (SPSS) software. Their findings show that women entrepreneurs spend less hours working as compared to men due to family-domestic responsibilities and concerns; their businesses are smaller than men's; women have a hard time deciding to begin a business; and women's businesses contribute less to a country's socioeconomic development. In Rwandese society, entrepreneurship is 


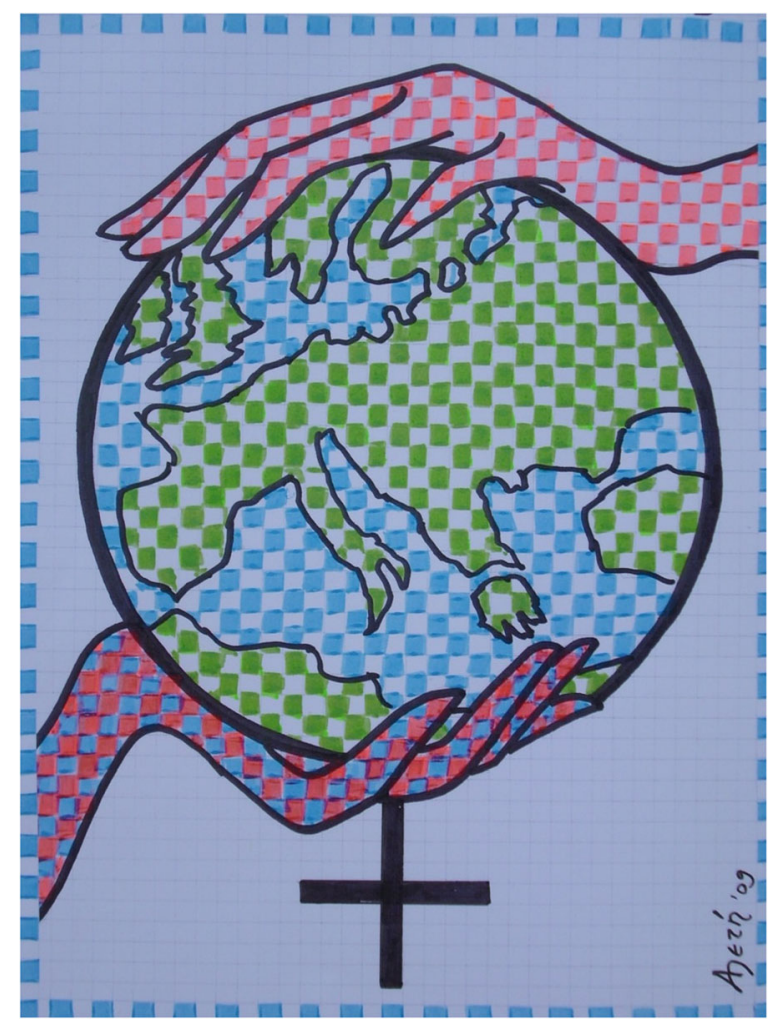

Fig. 3 Snapshots of empowered entrepreneurs

viewed as "a man-led activity and that is why it is not uncommon to find marginal contribution to business activity from womenfolk" (Nsengimana et al., 2018:152).

Regarding these marginal contributions of women entrepreneurs, according to the findings, the percentage of registered businesses by women showed $71.3 \%$ against $28.7 \%$ that were unregistered; $79.3 \%$ of the 398 women entrepreneurs had $1-3$ employees and $20.7 \%$ had $4-30$ employees. Regarding the source of start-up capital, their husbands contributed the most (39.7\%), followed by their own savings (33.2\%), and only $0.5 \%$ received bank loans. The majority $(79.1 \%)$ of the 398 women entrepreneurs were married, and $60.2 \%$ were between $29-43$ years old. As regards their level of education, $61 \%$ attended primary school and vocational/training while those with a high school

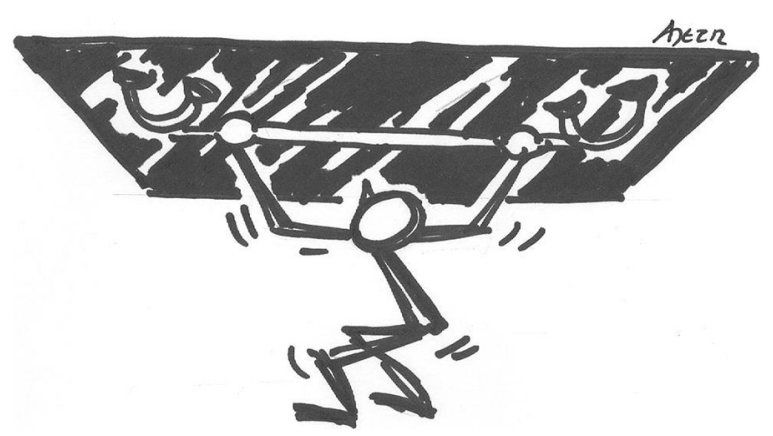

Fig. 4 Sociocultural barriers 
education accounted for $26.3 \%$. Only $11.7 \%$ attained tertiary education, and those without any formal training accounted for $1 \%$. They also point out that in Rwandese society, only in the last two decades, women are becoming involved in entrepreneurial activities to increase family income, among other things (Nsengimana et al., 2018).

A great body of literature points to the significance of entrepreneurship for empowerment, adding to family income, alleviating poverty, job creation and economic growth. Francesca Maria Cesaroni, Paola Demartini and Paola Paoloni (2017) discuss the implications of female entrepreneurship in "emerging countries" that are encouraging the creation of new businesses run by women, mainly Kenya, Indonesia, Nigeria, Egypt and South Africa. In their discussion on women in business and why women entrepreneurs and managers are using social media, they argue that in these countries, social media provides new opportunities, networking and flexibility for women. However, they too confirm that women not only lack basic digital skills, vital for succeeding as entrepreneurs, but also confront socio-cultural obstacles related to gender, which include the inability to maintain the work and private life balance.

How women overcome or rise above family constraints, the work-family conflict and invisible social barriers like the glass ceiling is also examined in the narratives of women leaders in Africa, the Middle East and the Far East. Chengadu and Scheepers (2017) discuss the barriers women face in non-western societies focusing on women in leadership roles in emerging markets, and specifically in the professions of engineering, accounting, consulting, law and medicine. Through the narratives of 50 female leaders, Chengadu and Scheepers (2017) examine how they navigate their careers, the challenges they face as well as their achievements, namely how these 50 women succeeded in overcoming sociocultural barriers in the organizations of their patriarchal societies. The findings indicate that a supportive family, along with the encouragement and support of the immediate social environment or community, among other things, enables women's advancement.

In a society where gender discrimination dominates, family and culture can either be a restriction or an enabler of female entrepreneurship, argues Nomusa Benita Mazonde (2016) in her dissertation, which examines culture and the self-identity of women entrepreneurs in a developing country. She focuses on the women entrepreneurs in Zimbabwe who are challenging conventional norms and social expectations and discusses their coping strategies, pointing out that relatively little research has explored the entrepreneurial experiences of women in the developing world.

Mazonde (2016) seeks to understand female entrepreneurship from the perspective of the female entrepreneurs themselves. Using a social constructivist theoretical perspective, she seeks to understand female entrepreneurs in terms of their subjectively constructed reality. In her study, 43 female entrepreneurs, whose businesses had transitioned from the informal economy to the formal economy, were observed and interviewed in depth. The findings indicate that their initial identities evolve through a journey of liberating-unshackling or unchaining themselves from imposed patriarchal structures to developing new identities. Their journey involved juggling family demands, domestic duties, work and diverse entrepreneurial activities, while relying solely on their personal expertise and their own financial resources. The findings show they were able to sustain their commitment to entrepreneurship and succeed due to the positive support of their families and communities. The driving force for their success 
was not profit alone, but a supportive social environment. The findings confirm that in such patriarchal societies, family and culture can either constrain or enable women's entrepreneurial ventures.

Female entrepreneurs in Africa, specifically the sub-Saharan region, experience a variety of constraints today, although they are actively involved as owners and/or managers of small and or/medium enterprises. In their thesis, Ernst Etim and Chux Gervase Iwu (2019) discuss the continued marginalization of female entrepreneurs in sub-Saharan Africa, arguing that "women are not seen as citizens" in a society where "citizenship has always been built in masculine terms".

Entrepreneurship in South Africa is examined as a gendered phenomenon in Yogavelli Nambiar's (2015) dissertation as well, which focuses on the development of "a unique psychosocial support ecosystem" for women entrepreneurs. South Africa is a country which has not succeeded in optimizing the entrepreneurial potential of its female population, which is $52 \%$ of the overall population, the majority young black African women living in townships.

Nambiar (2015), a social entrepreneur, examines the psychosocial barriers and enablers for women entrepreneurs in eight townships. She conducts qualitative semistructured interviews with 40 women entrepreneurs and five small business support organizatons in eight townships, three provinces of South Africa, and with five business development service providers. Her thesis, as previously cited, focuses on the development of "a unique psychosocial support ecosystem" (2015: 51) for women entrepreneurs, and specifically the influence of social factors and social expectations on individual thought and behavior. She examines existing support structures, traits and behaviors which could promote women's entrepreneurship, along with those that could inhibit or prevent it, such as lack of self-confidence, assertiveness, ambition and innovativeness. According to her findings, the top-ranking challenges or obstacles include (a) jealousy and lack of support from the community, (b) gender-related inequalities, (b) unsupportive family and friends who are discouraging of entrepreneurship, (c) critical or discouraging husbands, (d) lack of confidence in one's own ability to run and grow a business and (e) gender discrimination: not being taken seriously as a woman by different stakeholders, including purposeful intimidation, among other things. The results indicate insufficient knowledge of the pressures confronted by women entrepreneurs in the township social environment. On the other hand, one of the most important success factors is the support of friends and family, including emotional support, encouragement and some assistance related to the business.

Women are economically marginalized across South Africa, and although small, medium and micro-sized enterprises account for $40 \%$ of all businesses, women own only $8 \%$ of such enterprises. In South Africa, "male dominance of economic activities is extensive and permeates most industries", argue Obianuju E. Okeke-Uzodike, Ufo Okeke-Uzodike and Catherine Ndinda (2018:11).

Women's position is even worse in KwaZulu-Natal, one of South Africa's poorest provinces, with a population of 10.6 million, the country's second largest province both in terms of total population (21.3\%) and economic contribution of $16.5 \%$ of national gross value added (GVA). With this in mind, Okeke-Uzodike et al. (2018) examine the extent to which various government policies and initiatives have impacted on women's entrepreneurship in that province along with the challenges women entrepreneurs face. 
Their findings show the need to focus more on small, medium and micro-sized enterprises along with empowerment programs.

Empowering women to become entrepreneurial is high priority for the government of South Africa. The promotion of entrepreneurship and small business development are considered possible solutions to creating jobs, argue Natanya Meyer and Clarise Mostert (2016). Questionnaires were distributed to 14 female entrepreneurs enrolled in an adult entrepreneurship program at a South African University. The research methodology included a self-administered questionnaire developed by Meyer and Mostert (2016) which was compiled from an extensive literature review. The results showed that the main barriers women confronted were insufficient funding and inability to clarify goals. The most favorable success factors were customer care, quality of products or services and business skills.

Olawale Fatoki (2016) argues that women are heavily involved in entrepreneurship in South Africa due to the high rate of unemployment, poverty and social inequality. The majority of informal traders in South Africa are women with unregistered businesses and informal small-scale street trading involved in a variety of economic activities that contribute to economic growth: buying and selling clothes, as well as providing services, frequently from street pavements (i.e. haircuts). They do not produce products but provide services to customers. However, the failure rate for small businesses and informal traders is very high: around $70-80 \%$ fail within the first few years of operations due to insufficient financing, lack of managerial skills, high level of crime, strict government regulations as well as the inability to adopt ICTs to improve performance. Fatoki's (2016) study examines the types of ICTs used by women informal traders in South Africa and the obstacles they face, with data collected through structured interviews in a survey, including descriptive statistics and thematic analysis. The findings show a high failure rate for women due to lack of digital skills. Other obstacles include costaffordability; consequently, the main ICT used is the mobile phone. He also points out that small businesses in South Africa in general confront barriers in adopting ICTs due to lack of skill and high costs of ICT equipment, along with lack of knowledge about the potential benefits.

To promote the development of entrepreneurial culture in South Africa, Symentheus Mfundo Ndovela (2016) investigates the concept of entrepreneurial intent in Higher Education, using a sample of 250 final-year commerce students at the Durban University of Technology. The aim of the research was to investigate factors that influence a student's entrepreneurial intent. His findings show that the factors that have a direct impact on skills and employability, leading entrepreneurial intention are gender, culture, level of economic development and career identity. $\mathrm{He}$ also argues that graduates within South African higher education may possess the necessary theoretical knowledge but fall short when it comes to innovations. The findings - a result of a quantitative survey design implemented amongst a sample of 250 respondents (153 female students and 97 male) - show a positive relationship between individual risk-taking propensity and variables such as subjective norms, perceived behavioral control, proactive personality, entrepreneurial education and student attitude towards entrepreneurial education and intentions. Ndovela (2016) suggests that practitioners use the findings to come up with interventions that promote the development of an entrepreneurial culture in South Africa. 
Another study with university business students in Jordan discusses obstacles to women's entrepreneurship. Following their study with 254 female business students from a private and a public university who responded to a questionnaire, Salime Mehtap, Andrea Caputo and Massimiliao Matteo Pellegrini (2016) appealed to the universities and the Jordanian government to place more emphasis on practical entrepreneurial education, and especially in encouraging women to play a more active role within the workforce. Among the obstacles that worry potential female entrepreneurs in Jordan, according to their findings, are gender inequalities, the work-family conflict, lack of finance, fear of risk, lack of information and available opportunities and inability to make proper assessments. The "weakness" of the Jordanian economy is also cited as a main obstacle to women's entrepreneurship.

Women's entrepreneurial potential remains largely untapped in India as well, a society that "protects" women by "barring them from the social sphere" and keeping them "away from the limelight" (Rajani \& Panicker 2017). Women's social roles are restricted to those of the homemaker, child-bearer, domestic servant, taking care of the family and the elderly. The small number of women entrepreneurs in India and those attempting to venture into entrepreneurship are finding it extremely difficult, especially when trying to manage work, family and social obligations (Manimekalai 2016, Rastogi 2015).

Another barrier to entrepreneurship, as Shivakami Rajani and Sunita Panicker (2017) observe, are that women in India lack basic computer skills and knowledge of the English language, both necessary for the digital economy, adding that they are also "closeted in house chores" thus unable to network and get support to build or sustain their business. In this context, they discuss and applaud the work and contributions of an amazing social entrepreneur Manik Ajay Patwardhan in Bengaluru, which is the capital of the Indian state of Karnataka.

Manik has been encouraging and supporting other women entrepreneurs by providing them with advice, networking opportunities, technological training, marketing advice, a marketing platform, regular weekly meetings to motivate them, banking advice and financial information, and all this without any financial compensation: "Manik has nurtured many women to break out from the clutches of family commitment without compromising family ties; encouraged them to grow to face challenges and create success in their entrepreneurial ventures" (Rajani \& Panicker 2017). A significant point here is "without compromising family ties", which also indicates that the support of the family is vital in enabling women's entrepreneurship.

Lack of digital skills and the family-work conflict is also spotlighted in Ranjana Singh's (2017) doctoral thesis which discusses the barriers women entrepreneurs face in western India, specifically in the state of Gujarat. She interviewed 401 women, identifying education, family, inner zeal and will-power as vital enabling factors which elevated their motivation to perform. The greatest obstacles confronted were "dual role in home and business", to be exact, the family-career imbalance which prevails in all the narratives, interviews and studies cited in this article-including those related to western societies-in addition to poor knowledge of government support schemes, ignorance about banking procedures and formalities, poor knowledge of financial management, lack of leisure time and lack of technological skills. With regard to Singh's (2017) research limitations, specifically the barriers she confronted during her study, besides language, she emphasizes that the respondents had to seek their 
husbands' permission to participate in the interviews, specifically they required "husband's permission to give responses to the researcher."

Researchers in the developing world are re-addressing the balance of power within the family unit, including the status-quo of women in the Muslim world to facilitate discussions on how to best empower women through entrepreneurship, argue Muhammad Usama Anwar and Amber Gul Rashid (2012). In many patriarchal societies in the developing world, families play a major role in constraining or discouraging female entrepreneurship. Additionally, lack of government support discourages women's entrepreneurial activity. Businesses established by women are small scale and may not even be registered with the government, often due to complex registration procedures. To facilitate discussions on how best to empower women, they provide a review of female entrepreneurship in the developing world and subsequently focus on Pakistan. They discuss the concept of entrepreneurship and then go on to look at definitions for female entrepreneurship and entrepreneurial behavior.

Regarding women's entrepreneurship in Pakistan, "female entrepreneurship is in itself a different phenomenon as compared to male entrepreneurship, requiring a separate model to explain it", argue Anwar and Rashid (2012: 7), adding that both encompass varied aspects due to the different traditional expectations from these genders in the developing regions of the world. They assert that in traditional Muslim societies malefemale segregation is the norm and consequently female entrepreneurs guard their privacy and prefer a working environment which limits or totally excludes interactions with men. However, they do not include any interviews with such women to confirm their findings. Yet very briefly, in one paragraph, they refer to the great demand in the Pakistani market for women entrepreneurs who cater to women only! Specifically, the great need for female entrepreneurs who want to start female-only swimming classes, event management \& catering services and taxi/car-hire services. Could this be an opportunity for a new market for women entrepreneurs who target women only? Is it a means of empowerment or a means of reinforcing gender segregation?

In their discussion on the Pakistani culture, Anwar and Rashid (2012) point out that the mobility of females and their participation in self-employment is discouraged. Females are generally protected as it is a matter of family reputation and honor if women go out to work. The traditional perception is that the man is the breadwinner and the female is the caregiver and homemaker. This means that women may hesitate to become financially independent-whether as home-based workers or outside the homeas they fear that it would lead to family disputes and marital problems. The same applies to women who are thinking of starting their own business. Another obstacle to women's entrepreneurship in the developing world, they argue, is lack of education or illiteracy.

In Pakistan women entrepreneurs encounter a multitude of gender barriers, ranging from family obstacles, as previously cited, the social environment, societal expectations, gender perceptions and inevitably, personal insecurities (personality) and psychological constraints (fear of failure), the latter playing a significant role in performance: $27.7 \%$ of business activities in Pakistan do not even get started because of fear of failure, which however applies to both men and women. Anwar and Rashid (2012) conclude that more research is needed in urban and rural areas of Pakistan and specifically what is required is an examination of the differences in home-based versus non-home-based 
female entrepreneurs so as to acquire information-as there is a dire need to understand the issues in the lives of female entrepreneurs in order to encourage other females to also think about entrepreneurship-before making policy decisions. Next, they observe that information on home-based female entrepreneurs may be difficult to obtain by male researchers due to cultural factors, adding: "There is a dire need to give a voice to these faceless and voiceless females who play a big-yet in general unseenrole towards making a household financially stable" (Anwar \& Rashid, 2012: 22).

Another barrier repeatedly observed, not only in Pakistan but in many societies in the developing world, is lack of government support, access to financial resources and corruption. Although a government may devise different strategies and plans for female entrepreneurs, there is a major gap between the announcement and the implementation of these plans, along with corrupt officials, bribery, slow official procedures and heavy taxes. Female entrepreneurs rely on family funding, spouses support or personal savings. After family funding, they rely on donations, bank loans, governmental schemes and church charities. In most cases women are unable to provide collateral since they do not possess personal assets (Okeke-Uzodike et al. 2018; Nsengimana et al., 2018; Anwar \& Rashid, 2012; Kalim 2012).

Access to financing for women entrepreneurs, a major issue across the globe, is intensified or more difficult in such patriarchal societies. An example of limited access to financing is the previously cited study with 398 women entrepreneurs in Rwanda, of which only $0.5 \%$ received a bank loan to start their business, $33.2 \%$ used their own savings and the majority (39.7\%) received their start-up capital from their husbands (Nsengimana et al., 2018).

Despite barriers, women in the developing world are pursuing entrepreneurship because they have stronger incentives to create their own work environments at home. Women are motivated to establish a home-based business, as Ayesha Kalim (2012) argues, since their husbands have a lower degree of involvement in childcare and are less likely to support them in housework responsibilities. She also points out that the incentive to establish a home-based business is greater since low income countries are less likely to provide childcare facilities, health care services and training opportunities for women as employees.

The literature review indicates that among the significant enabling factors to women's entrepreneurship in the developing world are the support of the immediate social environment and community-including family and friends-which entails emotional support, encouragement and some assistance related to the business. Other enabling factors are education, funding, personal savings, knowledge of the English language and digital skills. The majority of female entrepreneurs rely on family funding, spouses support or personal savings. Essential behavioral characteristics or enabling attributes cited in the studies include: determination, inner zeal, will-power, coping strategies/skills; and developing new identities through their journey of liberating, unshackling or unchaining themselves from imposed patriarchal structures.

\section{Conclusions}

Women entrepreneurs continue to face the multitasking whirlpool, the work-life conflict, lack of financial resources and support services, inadequate business, management and marketing skills, poor access to information, business networks, technology and 
digital markets. Studies continue to argue that further research is required and that innovation or the drive for innovation is the first criteria for successful entrepreneurship. To encourage long-term female entrepreneurial involvement and foster socioeconomic development, researchers continue to call for the promotion and implementation of statutory policies and legal scholarship on entrepreneurship, including equal opportunity policies and well-defined property rights, the latter especially for women in the developing world.

Consequently, integrating the gender dimension is vital in eliminating this wastage of talent. Utilizing all human resources, the entire talent pool, means boosting innovation which is a prerequisite for economic growth and sustainable development. Reiterating Carayannis and Stewart (2013), "Learning-to-learn and learning-to-learn-how-to-learn" is also very important, in addition to focusing on personal intent, the personal characteristics and motivation of women entrepreneurs. This could assist policy makers to formulate programs supporting women in the start-up phase. Women business owners start and raise less capital than their male counterparts. This under-capitalization limits business significantly. So, it is important to consider gender-specific interventions, policies and practices that target exclusively women and also take into account cultural differences. For example, women's activism is contributing to filling these gender gaps in funding as more and more women are financing women entrepreneurs in the developing world.

Women entrepreneurs in Western societies are lending small amounts of money and interest-free loans to entrepreneurs in the developing world, along with providing marketing support and sharing their expertise and connections. The under-capitalization of women-owned firms places significant limits on their growth, argues Geri Stengel (2018), president of Ventureneer, a digital media and market research. In her article, she provides practical advice for overcoming gender barriers, informing her readers how women are helping women, such as Vicki Saunders who created SheEO's Radical Generosity to provide women entrepreneurs with larger interest-free loans and Jessica Jackley who co-founded Kiva to lend small amounts of money to entrepreneurs in the developing world.

\section{Future directions, the Blue Economy and the Silver Economy: degendering and the "olderpreneur"}

Gender integrations strategies are required in all social spheres, and not only in entrepreneurship. Despite extensive research and policy initiatives, gender gaps prevail, and not just in the developing world. This is a result of the deep-rooted gender order, to wit, sociocultural dynamics that are clearly reflected in the WEF, 2018 Global Gender Gap Report and Index (WEF, 2018), which on a global level shows fewer women are participating in the workforce, current trends indicating that the overall global gender gap could be closed in 108 years!

The WEF, 2018 Global Gender Gap Report and Index, using population-weighted group averages, benchmarks 149 countries on their progress towards gender parity across four thematic dimensions: (1) Economic Participation and Opportunity, (2) Educational Attainment, (3) Health and Survival and (4) Political Empowerment. Undeniably, gender integration strategies are needed in all social spheres. Progress towards gender parity, since 2006, is proceeding at different rates across the eight geographic 
areas examined in the Global Gender Gap Report (WEF, 2018). In Western Europe, for example, current progress rates indicate that the overall global gender gap can be closed in 61 years ${ }^{3}$.

So degendering-meaning applying or implementing gender-neutral standards and policies in the workplace (and in all social spheres) - is crucial in challenging the gender binary, eliminating gender divisions and dichotomous attitudes and increasing the number of women, not only in entrepreneurship, but in the workforce as well. In other words, degendering or integrating the gender dimension into the equation requires reproducing participation/engagement by promoting women in leadership positions as role models, along with emphasis on retention.

Recommendations and proposals-frequently cited in the studies-also include focusing on changing hegemonic structures, sexist cultures, gender stereotypes and mindsets; providing gender awareness and diversity training; sharing lessons learnt; eliminating the three gender gaps (the gender leadership, participation and pay gaps), in addition to other barriers to inclusion, such as the multitasking whirlpool, in other words encouraging and rewarding gender-neutral standards to promote or achieve gender integration and inclusion (Kamberidou, 2019).

As regards future directions and promoting gender integration-inclusion, women could also focus on emerging sectors, such as the Blue Economy and the Silver Economy. Blue Growth or the Blue Economy, refers to economic activities related to seas, oceans and coasts, along with the enablers of the Blue Economy/growth, meaning the sectors with high potential for future development, i.e. coastal tourism, fisheries, fish processing industry, maritime transport, desalination, ocean energy, seabed mining, marine biotechnology, etc. Oceans and seas-drivers for the economy-have great potential for innovation and growth. For example, as regards the European economy, Blue Growth represents approximately 5.4 million jobs and generates a gross added value of almost $€ 500$ billion a year (European Commission, 2019).

The United Nations (2018) report Leaving no one behind, which examines how Blue Growth can benefit women, youth, indigenous groups and migrants; emphasizes that Blue Growth unlocks the social and economic potential of marginalized groups, empowering them to safeguard natural resources while enhancing employment opportunities. It benefits communities and societies by supporting the sustainable development of aquatic resources, on which communities rely on for their livelihoods and food, maximizing environmental degradation from activities within the fisheries and aquaculture sector. Blue growth goals are closely aligned with the three pillars of the 2030 Agenda for Sustainable Development and its Sustainable Development Goals (SDGs) which focus especially on traditionally marginalized groups.

Additionally, concerning Europeans and Western societies in particular- where the sandwich generation no longer prevails-and in view of the current rapid rate of technological and demographic changes, women could focus on the Silver Economy. For example, Europe's older citizens constitute a large and growing segment in many consumer markets, as emphasized in the European Commission's final report on the

\footnotetext{
${ }^{3}$ Western Europe-with an average overall gender gap of $24.2 \%$ is home to four of the top 10 countries in the Index with regard to global rankings for 2018: Iceland (1st rank/position), Norway (2nd), Sweden (3rd), Finland (4th), Nicaragua (5th), Ruanda (6th), New Zealand (7th), the Philippines (8th), Ireland (9th) and Namibia (10th).
} 
Silver Economy which spotlights the economic activities relevant to the particular needs of older adults, such as leisure and wellbeing, health and nutrition, finance and transport, housing and education and employment. This includes policies, new services and products that will improve the quality of life of older adults, i.e. Silver tourism; robotics and games that help unburden or assist caregivers; integrated care services; agefriendly environments, including smart-homes; age-friendly universities; increased innovation of products; development of the market of mHealth devices (cardiac and neurological), sleep monitors and driverless cars (European Commission, 2018).

The final report of the European Commission (2018) on the Silver Economy-and its evolving economic activities provides an overview of the challenges for market development. Of particular interest here are the following sector-specific ideas:

- The Olderpreneur concept, which refers to the support and encouragement of actions for older adults to establish viable businesses, keeping them active and engaged in society, provides older citizens with opportunities to earn income, increases jobs and growth by supporting new business developments and increases opportunities for older people to work on service solutions and products tailored to the needs of the older adult.

- Interactive platform to fast-track product and service development, including intergenerational collaborations: setting up an interactive platform connecting people working on developing new solutions together with older people that want to support and/or invest in business development; sharing experiences with the younger generation or being involved in test-bed activities.

Future directions have already been discussed in the paper and summarized in the Conclusions as recommendations.

\section{Methods}

Focusing on current research (2011-2019), this literature review on women's entrepreneurial activities serves as a type of preamble or prelude to the "distinguished entrepreneur" (Carayannis \& Stewart 2013). This study seeks to answer the research question: How are women entrepreneurs transforming and challenging traditional understandings of professional success in the 21st century, despite the multitasking whirlpool. The goal is to spotlight, in today's digital world, the type of knowledge and skills required for successful entrepreneurship. This is done through an in-depth analysis of contemporary research (2011-2019) on women's entrepreneurial initiatives, characteristics, attributes, motives, challenges and leadership styles, while documenting strategies for success and barriers confronted. Research suggests that developed and developing nations alike have come to understand that women's entrepreneurial activities contribute to socioeconomic growth and sustainable development. The 21st century research examined in this study-as that of the late 20th century-highlights three major gender gaps in entrepreneurship (participation gap, pay gap and leadership gap), in addition to the work-life imbalance, while still arguing that further research is needed, and this for a topic extensively researched since the mid 1980s (Carlsrud \& Olm, 1986 et al.) and repeatedly associated with concepts of empowerment and leadership. 


\section{Acknowledgments}

I am particularly grateful to Professor Elias G. Carayannis—full Professor of Science, Technology, Innovation and Entrepreneurship at the George Washington University (GWU) School of Business in Washington, D.C.- for inspiring this work on women's entrepreneurial activities and making it possible. A special thanks, for her feedback and invaluable advice, to Dr. Nancy Pascall, DG CONNECT, Principal Administrator-Policy Coordinator at the European Commission in Brussels. My sincerest appreciation to the artist Areti Kamperidis for her contributions and permission to publish her artwork and sketches.

\section{Availability of data and material}

Not applicable

\section{Author's contributions}

The author read and approved the final manuscript.

\section{Author's information}

Dr. Irene Kamberidou is an Associate Professor of Sociology at the National and Kapodistrian University of Athens. She completed her BA and MA at Emmanuel College and Boston College, Boston and Chestnut Hill, Massachusetts respectively, and her junior year at the Sorbonne (Paris IV). Having repatriated to Greece, she completed her PhD at the Sociology Department of Panteios University of Social and Political Sciences in Athens. Irene is a member of the Hellenic Sociological Society (HSS), a founding member of the European Centre for Women and Technology (ECWT), and a member of the ECWT Executive. Having contributed as a member of the Gender Expert Action Group (GEAG) of the European Commission's Directorate-General for Information Society and Media in Brussels (2004-2009), she continues providing her support and services as a Gender Expert, addressing issues and research on exclusionary practices, gender diversity, integration and inclusion.

\section{Funding}

Not applicable

\section{Competing interests}

The author declares that she has no competing interests.

Received: 10 February 2019 Accepted: 8 January 2020

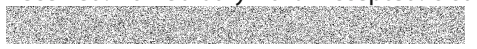

\section{References}

Abdul G. A. \& Hashmi, S. (2014). Marketing practices of small \& medium size enterprises: a case study of SME's in Multan District. European Journal of Business and Innovation Research, 2(6), 9-20. Publisher: European Centre for Research Training and Development UK (www.eajournals.org) http://www.eajournals.org/wp-content/uploads/Marketing-Practices-of-SmallMedium-Size-Enterprises-A-Case-Study-of-SME\%2D\%2D-s-in-Multan-District..pdf

Agarwal, S., \& Lenka, U. (2015). Study on work-life balance of women entrepreneurs-review and research agenda. Industrial and Commercial Training, 47(7), 356-362

Alsos, G.A., Hytti, U. \& Ljunggren, E. (Ed.) (2016). Research handbook on gender and innovation. Massachusetts: EE Edward Elgar Publishing, Northampton, MA https://www.e-elgar.com/shop/research-handbook-on-gender-and-innovation

Anwar, M.U \& Rashid, A.G (2012). Female entrepreneurs - a review of the literature and proposed conceptual framework. Institute of Business Administration (IBA), Karachi. Female Entrepreneurs. Proceedings of 2nd International Conference on Business Management (ISBN: 978-969-9368-06-6)

Bezergianni, S. (2013). Conceiving, exploring, and exploiting innovative ideas: from waste cooking oil to diesel Journal of Innovation and Entrepreneurship 2(9), 201 Springer Berlin Heidelberg. https://doi.org/10.1186/2192-5372-2-9

Buttner, E. H. (1993). Female business owners: How far have they come? Business Horizons, 18(2), 59-62

Carayannis E.G., Campbell D.F.J. (2018) Overview of cyber-development. In: Carayannis E., Campbell D., Efthymiopoulos M. (Eds), Handbook of Cyber-Development, Cyber-Democracy, and Cyber-Defense. Springer, Cham https://doi.org/10.1007/9783-319-09069-6_71

Carayannis, E. G., \& Meissner, D. (2017), Glocal targeted open innovation: challenges, opportunities and implications for theory, policy and practice The Journal of Technology Transfer, 42 (2), 236-252. Publisher Springer US

Carayannis, E.G and Stewart, M.R. (2013). Obsessed maniacs and clairvoyant oracles: empirically validated patterns of entrepreneurial behaviour Journal of Innovation and Entrepreneurship, 2(2), Springer, https://doi.org/10.1186/2192-5372-2-2

Carlsrud, A., \& Olm, K. (1986). The success of male and female business owners: a comparative analysis of the effects of multidimensional achievement motivation and personality traits. In R. Smilor \& R. Kuhm (Eds.), Managing takeoff in fast growth companies (pp. 147-162). New York: Praeger

Cesaroni, F. M., Demartini, P., \& Paoloni, P. (2017). Women in business and social media: implications for female entrepreneurship in emerging countries. African Journal of Business Management, 11(14), 316-326. https://doi.org/10. 5897/AJBM2017.8281

Chaganti, R. (1986). Management in women-owned enterprises. Journal of Small Business Management, 24(4), 18-29

Chengadu, S. \& Scheepers, C. (2017). Women leadership in emerging markets: featuring 50 women leaders. Routledge, (ISBN 1138188964, 9781138188969) https://books.google.gr/books?id=AplNvgAACAAJ\&dq=Women+Leadership+in+Emerging+ Markets:+Featuring+46+Women+Leaders\&hl=el\&sa=X\&ved=0ahUKEwi7-OTencrVAhWnDsAKHQBvADgQ6AEIJTAA

Coppola, S. (2018). Entrepreneurship: 'In Ghana, a newborn dies every 15 minutes. This PhD student will change that'. Teaching Humans to Thrive in the Age of Smart Machines, pp. 5-6. Northeastern University Magazine, Boston

Etim, E. \& Iwu, C.G. (2019). A descriptive literature review of the continued marginalisation of female entrepreneurs in subSaharan Africa. International Journal of Gender Studies in Developing Societies, Jan. 2019 Volume 3, Issue 1, pp. 1-19 https://doi.org/10.1504/JGSDS.2019.096755 https://www.inderscienceonline.com/toc/ijgsds/current 
European Commission (2014). Statistical data on women entrepreneurs in Europe-September 2014, Enterprise and Industry, PANTEIA Research to Progress. European Commission, Directorate-General for Enterprise and Industry Directorate DSMEs and Entrepreneurship Unit D.1 — Entrepreneurship and Social Economy. https://ec.europa.eu/growth/smes/ promoting-entrepreneurship/we-work-for/women_en

European Commission (2018). The Silver Economy, final report. A study prepared for the European Commission DG Communications Networks, Content \& Technology by Technopolis Group and Oxford Economics. https://doi.org/10. 2759/685036

European Commission (2019). What is the Blue Economy? Established sectors, Emerging sectors, Enablers (Data for 20162019), European Commission https://ec.europa.eu/maritimeaffairs/sites/maritimeaffairs/files/docs/publications/what-is-theblue-economy_en_1.pdf

Fagenson, E., \& Marcus, E. (1991). Perceptions of the characteristics of business owners: women's evaluation. Entrepreneurship Theory and Practice, 15(4), 33-47

Fatoki, O. (2016). The obstacles to the use of information and communication technologies by female informal traders in South Africa. Journal of Social Sciences, 49(3), 303-306 http://krepublishers.com/02-Journals/JSS/JSS-49-0-000-16-Web/ JSS-49-3-ii-000-16-Abst-PDF/JSS-49-3-ii-303-16-2115-Fatoki-O/JSS-49-SV-3-ii-303-16-2115-Fatoki-O-Tx\%5B3\%5D.pdf

Ferguson, F. E., \& Durup, M. J. R. (1997). Work-family conflict and entrepreneurial women: a literature review. Journal of Small Business and Entrepreneurship, 14(1), 46-57

Harrison, D. (2015). Handbook of research on digital media and creative technologies edited by Harrison, Dew. A volume in the Advances in Media, Entertainment and the Arts (AMEA) Book Series. IGI Global

Hisrich, R., \& Brush, C. (1987). Women business owners: a longitudinal study. In N. Churchill et al., (Eds.) Frontiers of business ownership research (pp.21-39). Wellesley. MA: Center for Entrepreneurial Studies, Babson College

Kalim, A. (2012). Women entrepreneurship. The emerging workforce in 21st century: turning challenges into opportunities. Proceedings of 2nd International Conference on Business Management, ISBN: 978-969-9368-06-6

Kamberidou, I (2013). Women entrepreneurs: 'we cannot have change unless we have men in the room' Journal of Innovation and Entrepreneurship, A SpringerOpen Journal, 2:6. https://doi.org/10.1186/2192-5372-2-6, http://www. innovation-entrepreneurship.com/content/2/1/6

Kamberidou, I. (2019). Gender integration in the military: gender-neutral standards and coed sports. European Journal of Physical Education and Sport Science, 5(11), 23-45. Open Access Publishing Group. https://doi.org/10.5281/zenodo.3364728 https:/oapub.org/edu/index.php/ejep/article/view/2566

Kamberidou, I. \& Fabry, E. (2012). Redefining professional success and concepts of excellence: integrating a gender perspective. In Reflections on Women in Entrepreneruship and ICT/ A reader (pp.10-27). Militos Emerging Technologies \& Services (www.gender-it.eu). In: http://scholar.uoa.gr/sites/default/files/ikamper/files/reflections_ on_women_in_entrepreneurship_and_ict_ladybiz_it.pdf

Kamberidou, I. \& Labovas, M. (2012). Social women share: technology as an enabler. In Reflections on Women in Entrepreneruship and ICT/ A reader (pp. 62-78). Militos Emerging Technologies \& Services (www.gender-it.eu). In: http:// scholar.uoa.gr/sites/default/files/ikamper/files/reflections_on_women_in_entrepreneurship_and_ict_ladybiz_it.pdf

Kamberidou, I., \& Pascall, N. (2020). The digital skills crisis: engendering technology-empowering women in cyberspace. European Journal of Social Sciences Studies, 4(6), 1-33. https://doi.org/10.5281/zenodo.3558799 https://oapub.org/soc/ index.php/EJSSS/article/view/683

Kelan, E. K. (2009). Gender fatigue: the ideological dilemma of gender neutrality and discrimination in organizations. Canadian Journal of Administrative Sciences. https://doi.org/10.1002/cjas.106

Khaire, R. J. (2011). Literature review of the women entrepreneurs and statutory policies. ZENITH International Journal of Multidisciplinary Research 1 (7), November, ISSN 22315780

Khan M.S. \& Rowlands, C. (2018). Mumpreneurship in New Zealand: an exploratory investigation, April 2018 International Journal of Sociology and Social Policy. Emerald Publishing Limited 2018 https://doi.org/10.1108/ISSP-08-2017-0106

Liliani, L., \& Urbanus, C. B. (2014). The role of female leadership and female entrepreneurship in business in Surabaya. Journal of Economics Business, and Accountancy Ventura, 17(1), 37-44

Loza, E (2011). Female entrepreneurship theory: a multidisciplinary review of resources. Twice a Year Scientific Journal. No. 1-2/2011. Copyright@ 2011 by Institute of Economic Sciences Belgrade, pp. 26-64

Malik, P. (2017). Gendering digital entrepreneurship: from research to practice using a tensional lens. ProQuest Dissertations Publishing: Purdue University http://docs.lib.purdue.edu/dissertations/AAl10266070/

Manimekalai, N. (2016). "Promoting women entrepreneurship through women entrepreneurs association of Tamil Nadu (WEAT) - an innovative value addition of entrepreneurship academic research to society - a case study in Tamil Nadu, India." 5th Annual International Research Conference- 2016 Faculty of Management and Commerce- SEUSL, pp. 128-142. http://ir.lib.seu.ac.lk/bitstream/handle/123456789/1913/Promoting\%20Women.pdf?sequence=1\&isAllowed=y, Promoting women entrepreneurship through women entrepreneurs association of Tamil Nadu (WEAT)

Mazonde, N.B (2016). Culture and the self-identity of women entrepreneurs in a developing country. A Doctoral thesis submitted to the Faculty of Commerce, Law and Management, University of the Witwatersrand, in fulfilment of the requirements for the degree of Doctor of Philosophy, Johannesburg, March 31st 2016. http://146.141.12.21/bitstream/handle/1053 9/21573/Thesis\%20Final\%20NBMazonde\%20final\%20print.pdf?sequence=1\&isAllowed=y

Mehtap S., Caputo A. \& Pellegrini M.M. (2016). Encouraging female entrepreneurship in Jordan: environmental factors, obstacles and challenges. Ramadani V., Dana L.P. Gerguri-Rashiti S. \& Ratten V. (Editors), Entrepreneurship and Management in an Islamic Context. Publisher: Springer International Publishing. https://doi.org/10.1007/978-3-319-396798_13

Meyer, N., \& Mostert, C. (2016). Perceived barriers and success factors of female entrepreneurs enrolled in an entrepreneurial programme. International Journal of Social Sciences and Humanity Studies, 8(1), 48-66

Mutalib, R.A., Arshad, R., Ismail N.S.A. \& Ahmad, Z. (2015). Women and entrepreneurship: an overview of women entrepreneurship programs in Malaysia. JGD vol. 11, Special Issue on Social Entrepreneurship, 15-28

Nair, S.R. (2015). Women entrepreneurship across nations: opportunities and challenges. Chapter 9: Handbook of Research on Entrepreneurship in the Contemporary Knowledge-Based Global Economy. Publisher: IGI Global, Editors: Neeta Baporikar, 189-216. https://doi.org/10.4018/978-1-4666-8798-1.ch009 
Nambiar, Y. (2016). The psychosocial support ecosystem for women entrepreneurs in townships: barriers and enablers. Gordon Institute of Business Science. University of Pretoria, 1-96. Research Report Submitted to the Gordon Institute of Business Science, University of Pretoria in partial requirement for the Master of Business Administration. http://hdl.handle. net/2263/52273,http://repository.up.ac.za/bitstream/handle/2263/52273/Nambiar_Psychosocial_2016.pdf?sequence= 1 \&isAllowed $=\mathrm{y}$

Ndovela, S. M. (2016). An investigation into entrepreneurial intent amongst final year Commerce students at the Durban University of Technology, by Ndovela, Symentheus Mfundo (20708003). Master of Technology in Business Administration, Department of Entrepreneurial Studies and Management, Durban University of Technology, South Africa: https://ir.dut.ac. $\mathrm{za} / \mathrm{xm}$ lui/bitstream/handle/10321/2527/NDOVELA_SM_2017.pdf?sequence=1\&isAllowed=y

Neider, L. (1987). A preliminary investigation of female business owners in Florida. Journal of Small Business Management, 25(3), 22-29

Nsengimana, S. Chux, G. I., \& Robertson, K. T. (2018). The downside of being a female entrepreneur in Kigali, Rwanda. SOCIOECONOMICA - Scientific Journal for Theory and Practice of Socio-economic Development 6 (12), 151-164. http://www. socioeconomica.info/sspui/handle/11171/267, http://hdl.handle.net/11171/267

Ohr, T. (2016). "TOP 50: Europe's most influential women in the startup and venture capital space". EU Startups Nov. 2, 2016 http://www.eu-startups.com/2016/11/top-50-europes-most-influential-women-in-the-startup-and-venture-capital-space/. (Accessed 4/14/2018)

Okeke-Uzodike, O. E., Okeke-Uzodike, U., \& Ndinda, C. (2018). Women entrepreneurship in Kwazulu-Natal: a critical review of government intervention politics and programs. Journal of International Women's Studies, 19(5), 147-164 Available at: http://vc.bridgew.edu/jiws/vol19/iss5/10

Pascall, A. N. (2012). Engendering technology, empowering women. London: Portia Ltd, Prince Consort, Albert Embankment

Phizacklea, A. (1988). Entrepreneurship ethnicity and gender - enterprising women. London: Routledge

Rastogi, R. (2015). Woman entrepreneurship, limitations and prospects. International Journal of Science, Technology \& Management, Volume No 04, Special Issue No. 01, March 2015, pp. 1770-1779. ISSN (online): 2394-1537, www.ijstm.com

Salamouris, I. (2013). How overconfidence influences entrepreneurship. Journal of Innovation and Entrepreneurship (2)8. Springer Berlin Heidelberg https://doi.org/10.1186/2192-5372-2-8

Scuotto, V., Serravalle, F., Murray, A., \& Viassone, M. (2019). The shift towards a digital business model. Women Entrepreneurs and Strategic Decision Making in the Global Economy. IGl Global. . https://doi.org/10.4018/978-1-5225-7479-8.ch007

Rajani, S., \& Panicker, S. (2017). Encouraging women into entrepreneurship- a case study of Manik Ajay Patwardhan. Zenith International Journal of Multidisciplinary Research, 7(1), 75-97 http://www.zenithresearch.org.in/images/stories/pdf/2017/ JAN/ZIJMR/8_ZIJMR_VOL7_ISSUE1_JAN_2017.pdf

Singh, R. (2017). Problems and prospects of women entrepreneurship with special reference to MSMEs in the state of Gujarat. A Thesis Submitted to Gujarat Technological University For the Award of Doctor of Philosophy In Management by Ranjana Singh, Supervision of Prof. S.O. Junare Gujarat Technology University, Ahmedabad. http://www.gtu.ac.in/uploads/ Thesis129990992024.pdf

Smeltzer, L. R., \& Fann, G. L. (1989). Gender differences in external networks of small business owners/managers. Journal of Small Business Management, 27(2), 25-32

Stengel, G. (2018). How more women are stepping up to fund women entrepreneurs in 2018 Forbes, Women@Forbes. Jan 3, 2018, 11:17 AM https://www.forbes.com/sites/geristengel/2018/01/03/a-rising-tide-of-women-fund-womenentrepreneurs-in-2018-and-beyond/\#6b8912033efe. Accessed 10 Feb 2019

Tavakol, N. (2017). The effect of changes (time, profession, etc.) on the position of women entrepreneur: We (women) can't make changes unless we have a man at home. Faculty of Business Economics and Entrepreneurship International Review Special Issues (2017 No. 1), 297-304. In: Special Issue of International Review, No.1. Current trends in organizational performance and future perspectives. Guest editor: Dr. Chou of Xanadu Linjie ISSN 2217-9739. Publisher Faculty of Business Economics and Entrepreneurship, Belgrade, Serbia: http://www.ijss-sn.com/uploads/2/0/1/5/20153321/ijss-isi_aug_ oa21_-_2017.pdf

Tran, K. (2014). The impact of digital media on female entrepreneurship. Trinity Washington University. Submitted to Dr. Donatus A. Uzomah on behalf of the faculty of the School of Professional Studies in partial fulfillment of the degree requirements for the Masters of Arts in Communication. [PDF] The Impact of Digital Media on Female Entrepreneurship

United Nations (2018). Leaving no one behind. How Blue Growth can benefit women, youth, indigenous groups and migrants. Food and Agriculture Organization of the United Nations (FAO), http://www.fao.org/3/CA0274EN/ca0274en.pdf. Accessed 24 Nov 2019

WEF (2018). The Global Gender Gap Report 2018. Insight Report. World Economic Forum (WEF), 1-367. http://www3.weforum. org/docs/WEF_GGGR_2018.pdf

Zahro, S. (2016). Applying entrepreneurship as a learning design for engineering education. World Transactions on Engineering and Technology Education, Vol.14, No.3, 410-415. WIETE: http://www.wiete.com.au/journals/WTE\&TE/Pages/Nol.14 $\% 20$ No.3\%20(2016)/12-Zahro-S.pdf

\section{Publisher's Note}

Springer Nature remains neutral with regard to jurisdictional claims in published maps and institutional affiliations. 